\title{
Rational Expectations and the Effects of Monetary Policy: A Guide for the Unimitiated
}

\section{A. Steven Holland}

T

HE success or failure of any course of action often depends on the ability to anticipate events that have not yet occurred, or that have occurred but are not yet known. The reat refum on an investment, for example, can be predieted but not actually known ai the time the investment decision is made. Since the failure to predict accurately the consequences of today's decisions can have significant costs, it pays for individuals to attempt to anticipate these consequences. To do this, a "rational" individual uses all of the information at his disposal to improve predictive accuracy. In general, this includes information about how the economy works and how the govemment conducts policy. Such an individual, thus, would have "mational expectations."

It is difficult to argue with the notion of rational expectations as described above, since the alternative implies that the individual ignores accessible information that would increase his foresight. It is, therefore, not surprising that the assumption of rational expectations has gained wide prominence in economic theory, to the point that one hears reference to the rational expectations "revolution." Rational expectations models, however, generally contain an additional element that has litte to do with the formation of expectations: the assumption of equilibium. In otherwords, supply is assumed to equal demand in all markets at all times. This is a departure from traditional "Keynesian" analysis, in which structural rigidities create disequilibrim, and a retum to classical

A. Steven Holland is an economist at the Federal Reserve Bank of St Louis. Laura A. Prives provided research assistance.
What is, pre-Keynesian analysis. Therefore, rational expectations theory is also sometimes referred to as the "new classical" economics.

Rational expectations models have altered the way economists view the role of economic policy. In strictest form, these models imply that government policies, including monetary policy, have no effect on real output - the policy ineffectiveness proposition. This proposition contrasts sharply with the standard Keynesian analysis of the effects of monetary policy, that is, that increased money growth results in both greater real output and higher inflation, implying a trade-of between inflation and unemplovment. It also contrasts with standard monetarist analysis, in which money is neutral in the long run, but has expansionary short-run effects. Not surprisingly, the policy ineffectiveness proposition has generated a great deal of controversy.'

This article has three major purposes: (1) to lay out the basic theory of rational expectations as it relates to monetary policy in a way that stresses its applicability to the real world, $(2)$ to discuss some of the ways that rational expectations models can be altered to give results that refute the policy ineffectiveness proposition and, most importantly, $(3)$ to assess the overall contribution of rational expectations theory to our understanding of the role of monetary policy. Regarding the latter, this paper stresses that the policy recommendation that frequently arises from rational expectations models - a more predictable monetary

1 For a sample of the variety of opinions among economists about rational expectations, see Lee (1984). 
policy - is essentially the same as that recommended by monetarists and depends critically on there being substantial costs to money growth's unpredictability. ${ }^{2}$

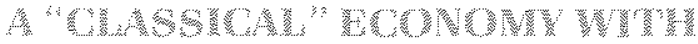

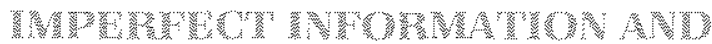

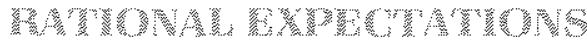

Expectations are rational in the manner described by Muth (1961) as long as the public's expectation of a variable to be forecast is based on what it knows about how that variable is determined. For example, individuals have some knowledge of how production, employment and pricing decisions are made, and they use this knowledge in making forecasts. Rational expectations models go beyond this fairly simple assumption, however, by stressing that all individuals make consistently optimal decisions. This is usually taken to mean that all markets are in equilibrium, since in disequilibrium, transactions could be made that benefit both buyer and seller.

An example of a model that incorporates these classical features is one in which each business firm maximizes the present value of expected real profit and each consumer maximizes the expected utility from real consumption. In such a model, a firm's production and employment of inputs generally depend on the current and expected future prices of its output and inputs relative to the general level of prices. Likewise, the demand for a firm's output is a function of its current and expected future relative prices and real consumer wealth. ${ }^{4} \mathrm{~A}$ key element of the model is that the supply of output increases as the producer per. ceives an increase in the price of his output relative to prices in general. ${ }^{3}$ As a simple example, consider a producer who uses only his own labor as an input, so that the relative price of his output equals his real wage. It pays for the producer to provide greater work effort in times of a higher real wage than in times of a

\footnotetext{
${ }^{2}$ Other descriptive treatments of rational expectations include Federal Reserve Bank of Minneapolis (1977). Berkman (1980), Maddock and Carter (1982) and Sheffin (1983)

More specifically, the corecast of a variable is its mathematical expectation based on some knowledge of the process that generates that variable.

The rate at which future returns are discounted may also be important in determining both supply and demand.

There is a supposition in rational expectations models that any change in relative prices is viewed as temporary. This is a reasonable assumption since a persistently higher relative price would attract additional entrants to the industry, thus driving the relative price back down.
}

lower real wage. This increase in labor supply results in greater output.

Relative prices are always changing due to a multi* tude of factors including consumers tastes and preferences, the technology used in producing various products and the avalability of productive mputs. An unanticipated change in one of these factors can be called a "real" shock. It is possible for real shocks to affect the aggregate price level as well as relative prices. At the same time, the aggregate price level could be changing due to a change in the supply of money. An unanticipated change in the money supply is a "nominal" shock.' For simplicity, it is assumed below that "aggregate" shocks are synonymous with nominal shocks, and real shocks are simply "relative" shocks.

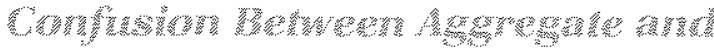

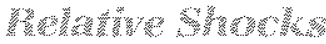

An important feature of most rational expectations models is the incomplete flow of current information across markets. Both producers and consumers lack complete information about curment prices in other markets, so that supply and demand depend on per ceptions of current relative prices rather than the actual (unknown) relative prices.

The producer who observes an unexpected increase in his price does not know whether it results from a relative shock - consumers are unexpectedly demanding more of his product and less of others or an aggregate shock - consumers demand more of all goods because of greater-than-anticipated money balances, resulting in a higher aggregate price level. This is an important distinction since the producer wishes to adjust output only in response to changes in relative prices, since he is maximizing real, not nominal, profit. Thus, if producers knew that rising prices were due only to an increase in the money supply, they would not adjust their output; instead, prices would increase in proportion to the increase in money supply. If the rational producer has experienced both

\footnotetext{
If the producer has to hire labor in addition to his own, an increase in the relative price of output leads to increased demand for labor, which dives up the real wage. Both the quantity of labor supplied and the level of production increase. This analysis also can be applied to inputs other than labor.

We ignore the possibility that shocks arise from unanticipated changes in the demand tor money.

${ }^{8} \mathrm{~A}$ model with this kind of partial information was first used by Phelps (1970), but also has been used by Lucas (1973), Barro (1976) and
} many others. 
relative and aggregate shocks in the past, then he cannot be sure that an unanticipated increase in the market price of his output reflects one kind of influence or the other; the producer will tend to assume, initially, that unanticipated price changes reflect some combination of both, until more information becomes avallable."

Unanticipated money growth has real effects in the rational expectations model described above. When money holdings rise faster than the anticipated price level, consumers perceive an increase in their real weath. They increase their demand for goods and services, causing an unanticipated increase in the general price level. Producers believe that their relative prices have increased and accordingly increase their output. Thus, the real effects of unanticipated money growth arise because perceived relative prices deviate from actual relative prices. ${ }^{\text {" }}$

\section{The NATUWA

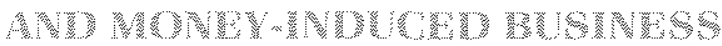 CWULES}

Although it was not stated explicitly, this analysis implies that unanticipated money growth causes output and unemployment to deviate from their "natural" levels in the short run. These natural levels refer to levels of output and unemployment that are consist ent with a long-term rate of growth of output and a rate of unemployment to which the economy tends to return after a disturbance. This notion is referred to as the "natural rate hypothesis."

Business cycles can be viewed as persistent lbut not permanent deviations of actual output and unemployment from their natural levels. Rational expectations models have been used to explain the existence of business cycles, despite the fact that information on the aggregate price level becomes known to producers and consumers at fairly short intervals. Business cycles can occur if, for example, unanticipated money growth results in increased capital investment. This requires that firms consider currently perceived rela tive prices, which are affected by monetary surprises, to be a good indicator of future real returns on investment. The effect of a higher rate of imvestment is

The more variable are aggregate shocks compared to relative shocks, the greater the proportion of a given unarticipated price increase attributed to aggregate influences. See Lucas (1973).

"Models that include this kind of wealth effect include Hercowitz (1981) and Cukierman (1982). They show that if the elasticities of supply and demand differ across markets, then monetary stocks also affect actual market-clearing relative prices and their variance. greater productive capacity and greater output over several periods. ${ }^{11}$

The behavior of inventories also plays a potential role in the persistence of the effect of nominal shocks. A firm that maintains an inventory can increase its sales in response to a perceived change in its relative price by selling out of its inventory. In later periods, the firm seeks to rebuild its inventory to its desired level, which requires additional production and employment. If firms gradually adjust inventories to their desired levels, then the effects of unanticipated money on output levels may persist for a fairly long period of time. ${ }^{2}$

Monetary surprises also can have persistent effects if the public is unable to distinguish perfectly between permanent and transitory shocks. Applied to money growth, this means that unanticipated money growth might represent either a one-time aberration with a return to the former expected money growth path, a permanent shift to a higher rate of money growth, or something in between. If rational forecasters have observed both permanent and transitory shocks in the past, then they will regard any unanticipated change in the growth rate of money as being partly pemanent and partly transitory. This means, for example, that expectations will adjust only gradually to an increase in the money supply that really is permanent. Forecasters, therefore, will underpredict the increase in money growth until their expectations adjust completely. In this way, nominal shocks can cause persistent changes in output and employment. ${ }^{13}$

"See Lucas (1975). Because the capital stock is not affected in the long run by nominal shocks, it must dectime from its greater-thannormal levels at some point in the future. It is worth noting that, despite the fact that the anticipated real return on investment is increased by unanticipated money growth, the actual real rate of interest declines. A monetary surprise implies that the money stock rises above anticipated inflation; that is, perceived real money batances increase. This induces individuals to increase their purchases of securities and goods until the real interest rate declines by enough to induce them to hold the larger amount of money. See Barro (1981)

:Btinder and Fischer (1981) bring out this point and analyze the case in which desired inventory levels are related negatively to the real interest rate. The decining real rate induced by unanticipated money growth (see footnote 11) leads to an increase in production and employment so that inventories can rise to the new desired levels. Brunner, Cukierman and Metzer (1983) take a different approach to the issue. In their model, goods have prices and quantities fixed for one period, but tinancial markets are free to adjust continually. The lower real interest rate caused by unanticipated money growth results in greater current consumption. With the de mand for goods higher than their fixed supply, firms sell off part of their inventories, then replenish them in later periods.

${ }^{13}$ See Brunner, Cukierman and Meltzer (1980). Note that this permanent/ransitory confusion implies that forecasts can display a persistent bias when viewed ex post, yet be completely rational ex ante. 


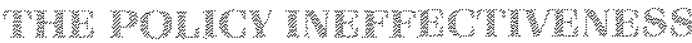

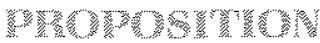

The rational expectations model presented above is based on three major assumptions: 11 there exist distinct markets across which montmation does not flow smoothly, (2) prices adjust instantaneously so that each individual market is in equilbrium in every period, and (3) expectations are formed rationaly. Sargent and Wallace 1975 , have shown that, in such a world, output is not affected by the decision to loluw any systematic monetary policy or "rthe" - the palicy ineffectiveness proposition. For example, it is irrelevant to the detemination of output whether the monetary authority chooses to control interest ates or the money supply. The public expects a cerian mate of money growth and adjusts its behavior in advance so that when the money growth actualy occurs, it afects nominal magnitudes the price level and the nominal Fate of interesti but not real magnitudes. Only money growth that deviates from the rate inplied by the monetary rule affects output, since it is unanticipated. ${ }^{1 .+}$

This differs from the outcome when expectations are not formed rationally, that is, when individuas ignore information that helps to prediet firure noney growth and inflation. In such a case, policymakers could exploit a trade-off between unemployment and inflation, increasing the growth rate of money in order to expand the economy. Since prices would lag behind changes in money, even policy actions that could be anticipated would affect real ouput and unemployment. Thus, to the extent that expectations are not rational, the particular monetary rule adopted has implications for the real sector.

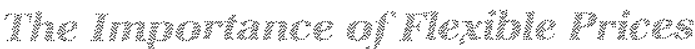

The assumption of price flexibility in this analys is critical to the conclusion that anticipated money growth has no effect on ouput. In reality, some prices do not adjust immedately to ether aggregate or relative shocks. Fixed-price contracts and the costs of adjusting prices mitigate against instantaneous price adjustment.

\footnotetext{
1*Note that it there were periect information about all markets, then money growth could never affect output, for, as Lucas (1975, p. 12) points out, "... in an economy in which all trading occurs in a single, competitive market, there is 'too much' information in the hands of traders for them ever to be "fooled' into attering real variables." This suggests that efficiency would be increased if there were a clearinghouse for contemporaneos's price information. It is unlikely, however, thaî such an institution could provide complete information in a timeiy manner in a large economy.

${ }^{15}$ The analysis below treats price inflexibility as though in arises solely from the existence of explicit price contracts: we recognize that there also are other potential causes.
}

Price contracts exist, al least party as a means of economizing on search costs for buyers. Fluctuating prices make inore dificult for buyers to find the seller will the lowest price for a given product. Therefore, firms have an incentive to announce their prices in advance, because they will lose some customers who value this infomation if they do not wiven the heterogeneity of goods produced in the economy, differing degrees of price flexibility arise. For example, goods that are storable tend to have less flexible prices than goods that are not stombe because fims can adjust inventory levels instead of prices to fuctuations in demand. In addition, goods that have customized features are more lkely to have their prices fixed for some period han goods haz are standardized across sellers. Therefone, some prices respond quickly to changes in the money stock while others respond more slowly.

As long as sorre prices are set in advance of the time that moneway policy actions are taken, even anticim paled money growth can have short-term real effects. For example, suppose a producer has a contract that specifes a nominal wage for his work force that remains fxed for a period of time. Assuming the contract camot be jenegotiated, any information that atrives after the contract is signed will not affect the nominal wage until the contract expires. The monetary authority, however is free to react to the new information in accordance with its policy rub. If this policy action causes noney growt hand the price level to be higher than orignaly anticipated, the producer will anticipate a dectine in the real wage it pays to labor over the remaining term of the contract. When the anticipated real wage dectines, the quantity of labot demanded increases and so do employment and production. ${ }^{\text {th }}$

The existence of long-term contracts, therefore, im-

\footnotetext{
16 See Alchian (1969).

TFor a more detaled discussion of the differences in price flexibility across products, see Bordo (1980), Gordon (1981) and Cartion (1982).

18 See Fischer (1977). For an analysis of price inflexibitity that takes a somewhat different approach, see Phelps and Taylor (1977). The problem with the analysis presented in the text is that it neglects the short-term labor supply effects that are so important in most rational expectations models. If both the supply and the demand curve for labor are relevant in the shon run, then deviations of actual from expected inflation in either direction result in lower employment and ouput. Furthemore, if a tim's output price is fixed while its input prices and the output prices ir other markets are flexible, then unanicipated inflation causes the price of inputs to rise relative to the fixed output price and the rative price of the fixed-price good to decline generally, resuling in reduced supply. it does not seem likely, however, that a firm that does not choose to have contracted wages would choose to have a contracted price.
} 
phes the potential tor the monetary authority to atfect real output in the shor ren, even if it follows a systematc policy. The structure of contracts depends, howwer, on the particular policy rule chosen. For example, if the policy rule allows the inflation mate to vary a great deal as a result of warous shocks, then the expectations upon which contracts are based are more thely to be contounded than if the inflation rate is keph farty stable. Theretore, whder he former policy rule, contracts are more likely to inchute cost-of-living ad justment clauses and provisions for reopening contract vegotations and to have shorem durtion than under the latter policy rule. This suggests that a change in policy from a rule in which intation remans stable to one in which it is allowed to vary would not be efrective in the long run, because the structure of contracts would change. These changes would cause prices to be more llexible, which would reduce or elminathe thects of antripated policy on the level of othout"

\section{B.

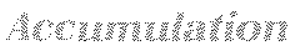

If the sublic expects the growth rate of money wo increase, will also expect higher infation in the future. Given certain instutional chanderistics of the economy, there are a number of ways in which expected infation can afect he accumulation of capital, even whth rational expectations. Thus, anticipated money will have rea efects, and the policy ineffectiveness proposition will not hold. For example, higher expected inflation causes people to shin part of their money balances into real capital, because money provides a very low or negative rea return dung times of inflation. ${ }^{2}$ on the oller hand, higher expected inflaton drives up the replacement cost of capital, while curren tax law provides for depreciation allowances for businesses based on the histoncal cost of apinal. Thus, the expected pal return on capital mestment is lowered, resuhing in less capial accumuation."

If the monetary authority were to continualy exploit the existence of eilne? a very low rea retum on morey holdings on distortions arising fom the tax

19Fiedman (1977) discusses the response of contracts to variable inflation.

20 See Wobin (1965). Fischer (1979) incorporates the Tobin eftect in a rational expectalions model.

2tSee Feidstein and Summers (1978). A lax on nommal interestaso inpiles that expected inflation affects capital acoumulation, if borrowers and lenders of invesiment funds have different tax rates. For a discussion of the impact oxpected intation on real interesi rates. see toland (1984). toatment of capital depreciation, however, it is likely that these instifutional characteristics would be eliminated. This is not as straightorward as the adjustment of private contracts discussed above, since it implies legislative rather than private action. But as inflation parsists, there will be a growing demand for savings instruments that combine the mansaction features of money with a market rate of retum, and investors will seek to eliminate the effects of inflation on the real value of depreciation allowances. If the political system allows these adjustments to occur, then the policy ineffectiveness proposition would still hold in the long run.

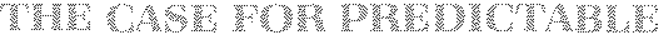

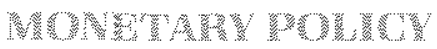

The foregoing analysis implies that, if a policy rule were to be enforced perfectly by the monetary authority, then in the long mo everyone would have comples knowledge of the monetary rule, and contracts and institutions would adjust to it. Thus, the behavios of the money supply would not affect real output, and any cychical bohaviot would arise purely from nonmonetary sources. ${ }^{2:}$ On the other hand, the monetary authority can affect the behavior of output in the short corm by departing from the rule or by altering the rule to lake advantage of institutional arrangements that likely would not continue to exist if they were continually exploited ${ }^{2+}$

An important contribution of the rational expectations movement, therefore, is that it shows that the sate of expectations and the institutional structure adiust to the way policy is conducted, thereby altering

${ }^{27}$ Casual evidence suggests that these kinds of institutional adjustments are indeed occurring, as transaction balances now may pay interest, and the recent Treasury Deparment proposal to reform the tax system includes a provision to alter the way inflation affects the depreciated value of capital. The recent change to an indexed personal income tax can also be viewed in this light if the taxation of nominal interest has affected capital accumulation (see footnote 21).

2:By a perfectly entorced monetary rule, I mean one in which there is no deviation of the quantity of money from what was intended due, for example, to changes in the demand for money. Shocks to money demand could have transitory effects on real output and employment.

24Taylor (1975) presents a different analysis of the behavior of output following a change in the monetary rule. In his model, there is a transition period during which forecasis display a persistent bias due to lack of knowledge about the nature of the change in policy. This is very similar to the notion of confusion between permanent and transitory shocks discussed above. The policy ineffectiveness proposition does not hold during this transition period, since the change in the monetary rule has real effects. 
the results of the policy. Thus, the effects of a given policy will not necessarily be the same every time it is used. This implies that econometric models that do not incorporate rational expectations are unlikely to predict accurately the results of a change in policy. This is the basis of the "Lucas critique." ${ }^{\prime 23}$

Since it is often possible to attain important shottterm benefts with policy measures that confound expectations, one might expect proponents of rational expectations to recommend secrecy in the conduct of monetary policy. This is not the case, however. Instead, they recommend that monetary policy be made as predictable as possible by sticking closely to preannounced rules. ${ }^{26}$ Implicit in this policy recommendation is the assumption that monetary variability taken here to be synonymous with uncertainty - imposes long-term costs in excess of its short-term benefits.

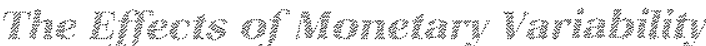

In general, greater monetary variability reduces the efficiency of the price system by making it more difficult to distinguish relative price increases from general inflation. In the standard rational expectations model, it is difficult to distinguish between relative and aggregate shocks, and the variability of each kind of shock plays an important role. If aggregate shocks, taken to be monetary surprises, become more variable compared to relative shocks, then a firm is more likely to perceive any change in its price as the result of aggregate rather than relative forces. It, therefore, will respond less - in terms of changing its levels of output, employment and invesiment - to an actual change in relative prices, even when the change is due to relative shocks. This means that the price system is less effective as a mechanism for allocating resources. ${ }^{27}$

\footnotetext{
25 See Lucas $(1976)$

${ }^{26}$ See, for example, Lucas and Sargent (1979).

${ }^{27}$ Cukierman (1982) shows that the difference between the perceived and actual relative price of a product grows larger, ceteris paribus, as monetary variability gets larger, implying a reduced efficiency of the price system, Cukierman and others also have shown that under certain conditions, greater monetary variability is associated with greater variability of relative prices. Furthermore, greater monetary variability also has the potential to affect real interest rates. The instability created by highly variable money growth makes for in creased uncertainty about future returns on capital and interestearning assets and raises the demand for money relative to these assets. This causes higher real interest rates. In other words, riskaverse lenders require that a greater "risk premium" be added to interest rates to offset the greater uncertainty associated with the future real return (see Mascaro and Meltzer (1983)). The effect is not unambiguously positive, however, since risk-averse borrowers re duce their demand for loanable funds as risk increases, which would tend to reduce the real rate.
}

Reduced efficiency in allocating resources lowers the natural level of output and potentially raises the natural rate of unemployment. The economy has ways of adapting, however, to the greater uncertainty caused by more variable money growth, including the greater use of indexing and the shortened duration of contracts. These adjustments reduce the risk associated with monetary variability, implying that the real effects of monetary variability should diminish as high levels of variability persist through time. The adjustments impose their own costs, however, since a larger amount of resources is diverted to the contracting process from other, presumably more efficient, uses, Thus, the economy still is likely to operate more efficiently in an environment of policy certainty than policy uncertainty. The analysis, therefore, implies that efficiency is enhanced by the use of well-defined and well-publicized policy rules."23

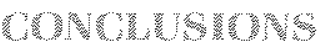

The incorporation of rational expectations into macroeconomic analysis leads one to the conclusion that the effects of monetary policy actions on real output and employment depend critically on the state of expectations and the existing institutional structure. If the public has sufficient knowledge about how policy is conducted and if institutions have adjusted to the conduct of policy, then the growth of the money supply will have no effect on real output or employment at all.

The monetary authority can always affect output in the short run by acting in a way that confounds expectations. Proponents of rational expectations, however, generally recommend that the policy authority not attempt to fool the public as a way of achieving shortterm goals, since there are potentially serious longterm costs associated with unpredictable policy. The most important of these are reductions in the "natural" levels of output and employment and a higher "natural" unemployment rate.

\footnotetext{
aGray (1978) presents a model in which greater monetary variability leads to both greater use of indexing and reduced duration of contracts. She also shows that greater use of wage indexing has another potential cost: by preventing changes in real wages, it reduces the ability of the economy to respond to real shocks.

29 In this analysis, the term monetary variability refers to the variability of unanticipated money growth. Note, however, that if there are long-term contracts, even the variability of anticipated money growth can have permanent real effects due to changes in the structure of contracts. For an example, see Canzoneri (1980).
} 
Whand

Alchian, Armen A. "Information Costs, Pricing, and Resource Unemployment," Westem Economic Joumal (June 1969), pp. 109 28.

Barro, Robert J. "Intertemporal Substitution and the Business Cycle," in Kanl Brunner and Allan H. Meltzer, eds., Supply Shocks, Incentives and National Wealth, Carnegie-Rochester Conference Series on Public Policy, Vol. 14 (Amsterdam: North-Holland, \$981), pp. 237-71.

"Rational Expectations and the Role of Monetary Policy," Journal of Monetary Economios (January 1976), pp. 1-32.

Berkman, Neil G. "A Rational View of Rational Expectations," New England Economic Review (January/February 1980), pp. 18-29.

Blinder, Alan S., and Stanley Fischer. "Inventories, Rational Expectations, and the Business Cycle," Journal of Monetary Economics (November 1981), pp. 277-304.

Bordo, Michael David. "The Effects of Monetary Change on Relative Commodity Prices and the Role of Long-Term Contracts," Journal of Political Economy (December 1980), pp. 1088-1109.

Brunner, Karl, Alex Cukierman, and Alian H. Meltzer. "Money and Economic Activity, Inventories and Business Cycles," Journal of Monetary Economics (May 1983), pp. 281-319.

"Stagflation, Persistent Unemployment and the Permanence of Economic Shocks, Journal of Monetary Economics (OCtober 1980), pp. 467-92.

Canzoneri, Matthew B. "Labor Contracts and Monetary Policy," Journal of Monetary Economics (April 1980), pp. 241-55.

Cariton, Dennis W. "The Disruptive Effect of Inflation on the Organization of Markets, ${ }^{\text {t* }}$ in Robert E. Hall, ed., Inflation: Causes and Effects (The University of Chicago Press, 1982), pp. 139-52.

Cukjerman, Alex. "Relative Price Variability and Inflation, A Survey and Further Results" (unpublished paper, University of Tel-Aviv, 1982).

Federal Reserve Bank of Minneapolis. "Rational Expectations Fresh Ideas That Challenge Some Established Views of Policy Making." Annual Report 1977, pp. 1-13.

Feldstein, Martin, and Lawrence Summers. "Inflation, Tax Rules, and the Long-Term Interest Rate, "Brookings Papers on Economic Activity (1: 1978), pp. $61-99$.

Fischer, Stanley. "Anticipations and the Non-neutrality of Money," Journal of Political Economy (April 1979), pp. 225-52.

"Long-Term Contracts, Rational Expectations and the Optimal Money Supply," Joumal of Political Economy (February 1977), pp. 191-205.

Friedman, Miton. "Nobel Lecture: Intlation and Unemployment," Journal of Political Economy (June 1977), pp. 451-72.
Gordon, Robert J. "Output Fluctuations and Gradual Price Adjustment," Joumal of Economic Literature (June 1981), pp. 493-530.

Gray, Jo Anna. "On Indexation and Contract Length," Joumal of Political Economy (February 1978), pp. 1-18.

Hercowitz, Zvi. "Money and the Dispersion of Relative Prices," Joumal of Political Economy (April 1981), pp. 328-56.

Holland, A. Steven. "Real interest Rates: What Accounts for Their Recent Rise?" this Review (December 1984), pp. 18-29.

Lee, Susan. "The Un-Managed Economy," Forbes (December 17 , 1984), pp. $147-58$

Lucas, Robert E., Jr. "Econometric Policy Evaluation: A Critique," in Karl Brunner and Allan $\mathrm{H}$. Meitzer, eds.. The Phillips Curve and Labor Markets, Carnegie-Rochester Conference Series on Public Policy, Vol. 1 (Amsterdam: North-Holland, 1976), pp. $19-46$.

"An Equilibrium Model of the Business Cycle," Journal of Political Economy (December 1975), pp. 1113-44

"Some International Evidence on Output-Inflation Tradeoffs," American Economic Review (June 1973), pp. 326-34.

Lucas, Robert E., Jr., and Thomas I. Sargent. "Atter Keynesian Macroeconomics," Federal Reserve Bank of Minneapolis Quarterly Review (Spring 1979), pp. 1-16.

Maddock, Rodney, and Michael Carter. "A Child's Guide to Rational Expectations," Journal of Economic Literature (March 1982), pp. $39-51$

Mascaro, Angelo, and Alan H. Meltzer. "Long- and Short-Term Interest Rates in a Risky World," Journal of Monetary Economics (November 1983), pp. 485-518.

Muth, John F. "Rational Expectations and the Theory of Price Movements," Econometrica (July 1961), pp. 315-35.

Phelps, Edmund S. "The New Microeconomics in Employment and Inflation Theory," in Edmund S. Phelps, ed., Microeconomic Foundations of Employment and inflation Theory (Norton, 1970).

Phelps, Edmund S., and John B. Taylor. "Stabilizing Powers of Monetary Policy under Rational Expectations," Joumal of Political Economy (February 1977), pp. 163 90

Sargent, Thomas J., and Neil Wallace. "Rational' Expectations, the Optimal Monetary Instrument, and the Optimal Money Supply Rule," Joumal of Political Economy (April 1975), pp. 241-54.

Sheffrin, Steven M. Rational Expectations (Cambridge University Press, 1983)

Taylor, John B. "Monetary Policy During a Transition to Rational Expectations," Journal of Political Economy (October 1975), pp. $1009-21$

Tobin, James, "Money and Economic Growth," Econometrica (OCtober 1965), pp. 671-84. 